Abstracta Iranica

Revue bibliographique pour le domaine irano-aryen

Volume 32-33 | 2013

Comptes rendus des publications de 2009-2010

\title{
Ellen Rehm. The Impact of the Achaemenids on Thrace: A Historical Review
}

\section{Astrid Nunn}

\section{OpenEdition}

1 Journals

\section{Édition électronique}

URL : http://journals.openedition.org/abstractairanica/40407

DOI : 10.4000/abstractairanica.40407

ISSN : 1961-960X

Éditeur :

CNRS (UMR 7528 Mondes iraniens et indiens), Éditions de l'IFRI

\section{Édition imprimée}

Date de publication : 1 décembre 2013

ISSN : 0240-8910

\section{Référence électronique}

Astrid Nunn, «Ellen Rehm. The Impact of the Achaemenids on Thrace: A Historical Review », Abstracta Iranica [En ligne], Volume 32-33 | 2013, document 111, mis en ligne le 01 juillet 2016, consulté le 27 septembre 2020. URL : http://journals.openedition.org/abstractairanica/40407 ; DOI : https://doi.org/ 10.4000/abstractairanica.40407

Ce document a été généré automatiquement le 27 septembre 2020.

Tous droits réservés 


\title{
Ellen Rehm. The Impact of the Achaemenids on Thrace: A Historical Review
}

\author{
Astrid Nunn
}

\section{RÉFÉRENCE}

Ellen Rehm. «The Impact of the Achaemenids on Thrace: A Historical Review », in : Jens Nieling, Ellen Rehm, eds., Achaemenid impact in the Black Sea. Communication of powers.

Aarhus, Aarhus University Press, 2010, p. 137-160. (Black Sea Studies, vol. 11).

1 L'A. récapitule ce que l'on sait de la Thrace à l'époque achéménide. Hérodote, Thucydide et Xénophon donnent le nom de forteresses qui jouèrent un rôle lors de la conquête de la Grèce et de certaines entités politiques locales tel le royaume des Odryses où habitaient de nombreuses tribus. Pour nous, la Thrace n'est pas mentionnée de manière reconnaissable dans les sources perses. L'équivalence entre le terme géographique de «Skudra » et Thrace est aussi peu résolue que la question de savoir si la Thrace était une satrapie ou si elle faisait partie de la satrapie de Phrygie hellespontique.

\section{AUTEURS}

\section{ASTRID NUNN}

Université de Munich 